JURNAL PENDIDIKAN, p-ISSN 2715-095X, e-ISSN 2686-5041

Volume 30, No.2, Juli 2021 (165-176)

Online: http://journal.univetbantara.ac.id/index.php/jp

\title{
Pengembangan Instrumen Evaluasi PPDB Model Contetx, Input, Process, Product (CIPP)
}

\author{
Winarto $^{1}$,Adnan Yusufi $^{2}$, Taufiq Khoirurrohman ${ }^{3}$, dan Dwi Hesty Kristyaningrum ${ }^{4}$ \\ 1,2,3,4 Fakultas Keguruan dan Ilmu Pendidikan Universitas Peradaban \\ Jl. Raya KM 03 Pagojengan Paguyangan, Brebes, Indonesia, E-mail: wiwin16@gmail.com
}

Received: March 22, $2021 \quad$ Accepted: May16, $2021 \quad$ Online Published: Juni 26, 2021

\begin{abstract}
Abstrak: Tujuan dari penelitian ini yaitu untuk mengembangkan instrument evaluasi PPDB sistem zonasi. Jenis penelitian ini adalah penelitian Research and Development (R\&D). Model pengembangan yang digunakan adalah 4D dari Thiagarajan (1974). Teknik sampel yang digunakan yaitu purpossive sampling. Teknik pengumpulan data menggunakan wawancara dan angket. Analisis data menggunakan statistik deskriptif. Hasil penelitian diperoleh (1) Instrumen dikembangkan berdasarkan studi pendahuluan belum ada dan perlu dikembangkan untuk melakukan evaluasi. (2) Instrumen evaluasi model CIPP yang dikembangkan layak dan valid digunakan berdasarkan hasil validasi ahli evaluasi, ahli pengukuran dan praktisi sekolah dengan kategori baik
\end{abstract}

Kata-kataKunci: Pengembangan, Instrumen, Evaluasi, PPDB; Zonasi; CIPP

\section{Development of PPDB Model Contetx Evaluation Instruments, Input, Process, Product (CIPP)}

\author{
Winarto $^{1}$, Adnan Yusufi ${ }^{2}$, Taufiq Khoirurrohman ${ }^{3}$, and Dwi Hesty Kristyaningrum ${ }^{4}$ \\ 1,2,3,4 Fakultas Keguruan dan Ilmu Pendidikan Universitas Peradaban \\ Jl. Raya KM 03 Pagojengan Paguyangan, Brebes, Indonesia, E-mail: wiwin16@gmail.com
}

\begin{abstract}
The purpose of this research is to develop a zoning system PPDB evaluation instrument. This type of research is a Research and Development $(R \& D)$ research. The development model used is $4 D$ from Thiagarajan (1974). The sample technique used is purposive sampling. Data collection techniques using interviews and questionnaires. Data analysis using descriptive statistics. The research results were obtained (1) The instrument was developed based on a preliminary study that did not exist and needed to be developed to conduct an evaluation. (2) The CIPP model evaluation instrument developed was feasible and valid to use based on the validation results of evaluation experts, measurement experts and school practitioners with good categories.
\end{abstract}

Keywords: Development, Instruments, Evaluation, PPDB; Zoning; CIPP

\section{Pendahuluan}

Kementerian Pendidikan dan Kebudayaan (Kemendikbud) menerbitkan Peraturan Menteri Pendidikan (Permendikbud) No. 14 Tahun 2018 tentang PPDB pada Taman Kanak-Kanak, Sekolah Dasar, Sekolah Menengah Pertama, Sekolah Menengah Atas, Sekolah Menengah Kejuruan, atau Bentuk Lain yang Sederajat. Poin penting dalam 
regulasi ini, kriteria utama dalam penerimaan siswa adalah zonasi atau jarak antara rumah dengan sekolah. Sementara nilai ujian nasional yang diperoleh di jenjang pendidikan sebelumnya bukan lagi pertimbangan utama (Suwarto, 2009). Praktiknya, sistem zonasi PPDB menuai pro kontra di sejumlah daerah, termasuk di Kabupaten Brebes. Data studi pendahuluan tahun 2019 tentang permasalahan di Brebes yaitu sejumlah tujuh belas SMA Negeri hanya satu sekolah yang daya tampungnya terpenuhi sebanyak 408 siswa. Permasalahan tentang PPDB yaitu kesalahan sistem ini membuat puluhan calon siswa yang akan mendaftar, berkaitan dengan perpindahan tempat tinggal tiba-tiba, kewajiban menerima 90 persen calon siswa yang tinggal di lokasi dekat sekolah. Di lapangan, hal ini membuat sekolah yang jauh dari konsentrasi pemukiman warga biasanya ada di pusat kota sepi peminat sehingga menimbulkan ketimpangan karena ada sekolah yang pendaftarnya melebihi kuota dan ada sekolah yang sepi pendaftar. Oleh karena itu, peneletian pengembangan instrumen evaluasi model CIPP, perlu dilakukan.

Penelitian evaluasi PPDB model CIPP memiliki kebaruan sejauh peneliti cermati dari penelitian yang sudah dilakukan oleh peneliti lain yaitu mengembangkan evaluasi PPDB model CIPP, Topik evaluasi sistem zonasi lebih banyak menyoroti implementasi PPBD dan belum membahas instrumen penelitian. Penelitian tentang evaluasi penerimaan sistem zonasi di luar negeri Poder, Lauri, Veski (2016) kebijakan sistem zonasi tidak mempengaruhi orang tua siswa memilih sekolah negeri akan tetapi persepsi kualitas sekolah yang menjadi faktor pemilihan sekolah bagi anaknya. Irawati, Purwanti, dan Adiwisasatra,dkk (2019) disimpulkan kebijakan sistem zonasi terbukti dapat meningkatkan angka partisipasi kasar dari siswa RMP,karena faktanya tidak semua anak RMP berdomisili di dekat sekolah. Marini (2019) hambatan yang ditemukan PPDB sistem zonasi yakni aplikasi yang disediakan mengalami gangguan, jaringan kurang memadai, kuota diluar sistem zonasi mempengaruhi tidak terpenuhinya daya tampung. Perdana (2019) pelaksanaan PPDB Zonasi di Provinsi Sulawesi Tengah telah berhasil dalam upaya memeratakan akses dan mutu pendidikan. Sebaran siswa dari sisi jarak sudah mendekat ke rumah siswa dan dari sisi mutu input juga telah menyebar di berbagai sekolah sehingga sudah tidak ada lagi dikotomi sekolah unggulan dan non unggulan. Ardhi (2015) Implementasi PPDB dengan mekanisme zonasi menimbulkan masalah yaitu masih belum disosialisasikan, terkendala oleh faktor teknis, kuota penerimaan siswa baru yang kurang, dan persaingan yang tinggi antar sekolah. Jadi prasetyo (2018) rekomendasi berdasarkan hasil penelitian kepada pemerintah untuk melanjutkan kebijakan ini, mempromosikan moda transportasi umum serta moda transportasi sehat bagi pelajar, penambahan kapasitas daya tampung sekolah negeri, serta evaluasi lebih lanjut secara komprehensif terhadap kebijakan sistem zonasi ini. Widayanti dan Rosdiana (2018) hasil evaluasi berhasil dilaksanakan sesuai dengan pedoman petunjuk teknis PPDB, meskipun terdapat masalah jalur mitra warga memiliki peminat yang rendah. Dalam evaluasi dunia pendidikan tidak lain adalah sebagai tolak ukur dalam mencapai tujuan pendidikan (Suwarto, 2017).

Evaluasi pendidikan adalah proses membuat penilaian tentang prestasi, nilai, atau nilai program pendidikan (Gall, Gall and Borg, 2007). Penerimaan Peserta Didik Baru (PPDB) sistem zonasi merupakan sebuah program yang diselenggarakan sekolah. Menurut Sanders (1979) dalam Murzyanah, 2011) mengatakan evaluasi program merupakan proses deskripsi, pengumpulan data dan penyampaian informasi kepada pengambil keputusan yang akan dipakai untuk pertimbangan apakah program perlu diperbaiki, dihentikan atau diteruskan. Tujuan evaluasi program 
seperti yang duraikan oleh Roswati (2008:66-67) adalah sebagai berikut: 1) menjawab pertanyaan-pertanyaan tentang tindak lanjut suatu program di masa depan, 2) penundaan pengambilan keputusan, 3) penggeseran tanggung jawab, 4) pembenaran/justifikasi program, 5) memenuhi kebutuhan akreditasi, 6) laporan akutansi untuk pendanaan, 7) menjawab atas permintaan pemberi tugas, informasi yang diperlukan, 8) membantu staf mengembangkan program, 9) mempelajari dampak/akibat yang tidak sesuai dengan rencana, 10) mengadakan usaha perbaikan bagi program yang sedang berjalan, 11) menilai manfaat dari program yang sedang berjalan, 12) memberikan masukan bagi program baru.

Penelitian tentang evaluasi program pada PPDB sistem zonasi belum banyak mengungkap instrumen evaluasi PPDB sistem zonasi. Prasetya (2018) rata-rata jarak tempat tinggal dengan sekolah dan biaya transportasi pelajar SMA di DIY mengalami penurunan signifikan setelah diberlakukannya kebijakan sistem zonasi dalam PPDB. Hal itu berarti bahwa kebijakan ini bisa dikatakan telah berhasil mencapai tujuannya dan berdampak positif bagi masyarakat. Namun secara sosial terdapat kendala yaitu orang tua kurang mendukung dengan mengeluh terkait sistem zonasi dalam pelaksanaan PPDB. Irawati, Purwanti, dan Adiwisasatra (2019) menyimpulkan bahwa kebijakan sistem zonasi terbukti dapat meningkatkan angka partisipasi kasar dari siswa RMP,karena faktanya tidak semua anak RMP berdomisili di dekat sekolah. Marini (2019) bahwa hambatan yang ditemukan PPDB sistem zonasi yakni aplikasi yang disediakan mengalami gangguan, jaringan kurang memadai, kuota diluar sistem zonasi mempengaruhi tidak terpenuhinya daya tampung. Perdana (2019) menyimpulkan bahwa pelaksanaan PPDB Zonasi di Provinsi Sulawesi Tengah telah berhasil dalam upaya memeratakan akses dan mutu pendidikan. Sebaran siswa dari sisi jarak sudah mendekat ke rumah Siswa dan mutu input juga telah menyebar di berbagai sekolah sehingga sudah tidak ada lagi dikotomi sekolah unggulan dan non unggulan. Penelitian yang akan dilakukan yaitu mengembangkan instrumen evaluasi PPDB sistem zonasi menggunakan model CIPP.

Stufflebeam (1972) bahwa Evaluasi model Stufflebeam terdiri dari empat dimensi, yaitu: context,input, process, dan product, sehingga model evaluasinya diberi nama CIPP. Evaluasi model ini bermaksud membandingkan kinerja dari berbagai dimensi program dengan sejumlah kriteria tertentu. Menurut model ini keempat dimensi program tersebut perlu dievaluasi sebelum, selama dan sesudah program diklat dikembangkan Mahmudi (2011) bahwa Model CIPP berpijak pada pandangan bahwa tujuan terpenting dari evaluasi program bukanlah membuktikan (to prove), melainkan meningkatkan (to improve). Model CIPP merupakan salah satu model yang banyak digunakan untuk mengevaluasi program pendidikan. Penelitian Musyaroh dan Sutrisno (2014) mengembangkan instrumen evaluasi program Tahfiz Alqur'an di Pondok Pondok Pesantren ditemukan kesenjangan sarana belajar, kinerja guru, dan motivasi belajar santri. Kurnia, Rosana, Supahar (2017) instrumen evaluasi model CIPP yang digunakan untuk mengevaluasi pelaksanaan penilaian portofolio dan hasilnya menunjukkan bahwa pelaksanaan penilaian portofolio di Sekolah Menengah Pertama di Yogyakarta berada dalam kategori baik. Asfaroh, Rosana, Supahar (2017) instrumen evaluasi model CIPP yang digunakan untuk mengevaluasi pelaksanaan penilaian proyek dan hasilnya menunjukkan bahwa pelaksanaan penilaian proyek di Sekolah Menengah Pertama di Yogyakarta berada dalam kategori baik. 
Berkaitan dengan sistem Zonasi Peraturan pemerintah tentang sistem zonasi dalam melaksanakan PPDB digunakan sebagai dasar pedoman untuk mengembangkan instrumen evaluasi. Instrumen yang dikembangkan untuk mengukur ketercapaian programKementerian Pendidikan dan Kebudayaan (Kemendikbud) menerbitkan Peraturan Menteri Pendidikan (Permendikbud) No. 14 Tahun 2018 tentang PPDB pada Taman Kanak-Kanak, Sekolah Dasar, Sekolah Menengah Pertama, Sekolah Menengah Atas, Sekolah Menengah Kejuruan, atau Bentuk Lain yang Sederajat. Poin penting dalam regulasi ini, kriteria utama dalam penerimaan siswa adalah zonasi atau jarak antara rumah dengan sekolah. Sementara nilai ujian nasional yang diperoleh di jenjang pendidikan sebelumnya bukan lagi pertimbangan utama yaitu: (1). Pasal 16 yang berbunyi sekolah yang diselenggarakan oleh pemerintah daerah wajib menerima calon peserta didik yang berdomisili pada radius zona terdekat dari sekolah paling sedikit $90 \%$ (Sembilan puluh persen) dari total jumlah peserta didik yang diterima. (2). Domisili calon peserta didik sebagaimana dimaksud pada ayat (1) berdasarkan alamat pada kartu keluarga yang diterbitkan paling lambat 6 (enam ) bulan sebelum pelaksanaan PPDB. (3). Radius zona terdekat sebagaimana dimaksud pada ayat (1) ditetapkan oleh pemerintah daerah sesuai dengan kondisi di daerah tersebut berdasarkan. (a) Ketersediaan anak usia sekolah di daerah tersebut, dan (b) Jumlah ketersediaan daya tampung dalam rombongan belajar pada masing-masing sekolah. (4). Dalam menetapkan radius zona sebagaimana dimaksud pada ayat (3), pemerintah daerah melibatkan musyawarah/kelompok kerja kepala sekolah. (5). Bagi sekolah yang berada provinsi/kabupaten/kota, di daerah ketentuan perbatasan persentase dan radius zona terdekat sebagaimana dimaksud pada ayat (1) dapat diterapkan melalui kesepakatan secara tertulis antar pemerintah yang saling berdekatan. (6). Sekolah yang diselenggarakan oleh pemerintah daerah dapat menerima calon peserta didik melalui : a. Jalur prestasi yang berdomisili di luar radius zona terdekat dari sekolah paling banyak 5\% (lima persen) dari total jumlah keseluruhan peserta didik yang diterima, dan b. Jalur bagi calon peserta didik yang berdomisili di luar zona terdekat dari sekolah dengan alasan khusus meliputi perpindahan domisili orang tua/wali peserta didik atau terjadi bencana alam/sosial, banyak 5\% (lima persen) dari toatal paling jumlah keseluruhan peserta didik yang diterima.

Berkaitan dengan masalah penelitian mengenai sistem PPDB membuat sekolah yang jauh dari konsentrasi pemukiman warga biasanya ada di pusat kota sepi peminat sehingga menimbulkan ketimpangan karena ada sekolah yang pendaftarnya melebihi kuota dan ada sekolah yang sepi pendaftar. Selain itu evaluasi sistem zonasi yang lebih banyak menyoroti implementasi PPBD dan belum membahas instrumen penelitian. Oleh karena itu, rumusan penelitian ini bagaimanakah kelayakan instrumen evaluasi PPBD sistem zonasi dan bagaimanakah keberhasilan instrument tersebut untuk memberikan perbaikan pada penerimaan peserta didik baru. Tujuan penelitian yaitu mengembangkaninstrumen evaluasi PPDB sistem zonasi dengan model CIPP (Context, Input, Proces, Product) khususnya untuk wilayah Brebes Selatan.

\section{Metode Penelitian}

Penelitian ini merupakan jenis penelitian kuantitatif dengan menggunakan pendekatan Research and Development (R\&D). Produk yang dikembangkan dalam 
penelitian ini berupa instrument penelitian evaluasi model CIPP. Model pengembangan yang digunakan dalam penelitian ini mengacu pada model ;.pengembangan 4D yang dikemukakan oleh Thiagarajan (1974) yang terdiri dari define, design, development, dan dissemination.Penelitian ini dilakukan dari 25 April sampai dengan 28 Oktober 2020. Tempat penelitian ini di Sekolah Menengah Atas (SMA yang berada di wilayah Brebes Selatan. Populasi dalam penelitian ini adalah Siswa seluruh SMA yang berada di wilayah Brebes bagian selatan. Teknik pengambilan sampel yang digunakan adalah purpossive sampling. Purpossive sampling adalah teknik penentuan sampel dengan pertimbangan tertentu. Sampel dalam penelitian ini adalah SMA N 1 Sirampog.

Langkah-langkah penelitian yang dilakukan dalam penelitian ini mengacu pada langkah-langkah pengembangan pada model 4D yang dikemukakan oleh Thiagarajan (1974). Desain 4D terdiri dari 4 tahap yaitu pendefinisian (Define), perancangan (Design), pengembangan (Develop) dan penyebaran (Desiminate). Penelitian ini dilaksanakan: kegiatan tahap define. Tahap define melakukan analisis studi kebutuhan berupa kegiatan observasi pembelajaran dan wawacara terhadap kepala sekolah dan panitia PPDB. Selanjutnya, tahap design adalah merancang produk berupa instrument evaluasi PPDB. Instrumen evaluasi yang disusun berdasarkan model evaluasi CIPP. Kemudian, tahap development (Pengembangan) adalah kegiatan membuat rancangan menjadi produk dan menguji validitas produk secara berulang ulang sampai dihasilkan produk sesuai dengan spesifikasi yang ditetapkan. Pada tahap ini meliputi (a) validasi ini dilakukan oleh ahli pengukuran, ahli evaluasi dan praktisi yang berkompeten untuk memberikan penilaian dan saran pada produk; (b) uji coba kelompok kecil atau terbatas; (c) uji coba terbatas dilakukan pada responden berjumlah delapan (d) Uji coba lapangan dilakukan pada semua SMA di Brebes wilayah selatan. Tahap terakhir dalam penelitian ini yaitu Dissemination (Diseminasi). Tahap dissemination (diseminasi) yaitu kegiatan menyebarluaskan produk yang telah teruji untuk dimanfaatkan orang lain. Tahap ini merupakan tahap penggunaan perangkat yang telah dikembangkan pada skala yang lebih luas, misalnya diberikan pelatihan dan workshop pada panitia PPDB. Pada tahap ini hanya dilaksanakan melalui pembuatan jurnal dan memberikan pedoman evaluasi ke pihak sekolah.

Instrumen yang digunakan untuk mengumpulkan data pada penelitian ini adalah lembar angket untuk validasi ahli untuk menilai produk yang dikembangkan, pedoman wawancara panitia PPDB untuk melakukan studi pendahuluan. Teknik analisis data yang digunakan analisis deskriptif kuantitatif yaitu data kuantitatif yang diperoleh melalui angket validasi di konversikan ke data kualitatif. Adapun Pengubahan skor skala lima mengacu pada pengkategorisasian dan disajikan pada Tabel 1.

Tabel. 1. Pengkategorisasian skor skala lima

\begin{tabular}{cccc}
\hline Vo & Rentang Skor & Skor & Kategori \\
1 & $\mathrm{X}>\mathrm{Xi}+1,8 \mathrm{Sbi}$ & $>4,2$ & Sangat Baik \\
2 & $\mathrm{Xi}+0,6 \mathrm{Sbi}<\mathrm{X} \leq \mathrm{Mi}+1,8 \mathrm{Sbi}$ & $>3,4-4,2$ & Baik \\
3 & $\mathrm{Xi}-0,6 \mathrm{Sbi}<\mathrm{X} \leq \mathrm{Mi}+0,6 \mathrm{Sbi}$ & $>2,6-3,4$ & Cukup \\
4 & $\mathrm{Xi}-1,8 \mathrm{Sbi}<\mathrm{X} \leq \mathrm{Mi}-0,6 \mathrm{Sbi}$ & $>1,8-2,6$ & Kurang \\
5 & $\mathrm{X} \leq \mathrm{Xi}-1,8 \mathrm{Sbi}$ & $\leq 1,8$ & Sangat kurang \\
\hline
\end{tabular}

Sumber: Widoyoko (2016)

Keterangan : 


$$
\begin{aligned}
& \mathrm{X}=\text { skor aktual }(\text { skor yang dicapai }) \\
& \mathrm{Xi}=\text { rerata skor ideal }=(1 / 2)(\text { skor tertinggi ideal }+ \text { skor terendah ideal }) \\
& \mathrm{Sbi}=\text { simpangan baku skor ideal }=(1 / 6)(\text { skor tertinggi ideal }- \text { skor terendah ideal })
\end{aligned}
$$

\section{Hasil Penelitian}

Data penelitian yang sudah diperoleh pada tahap define dan design dan develop. Tahap define dilakukan studi pendahuluan dengan memberikan angket kepada guru yang bertugas sebagai ketua panitia, melalui layanan google form.

\section{Tahap Define}

Tahap define dilakukan studi pendahuluan dengan memberikan angket kepada guru/panitia PPDB yang sudah menerapkan sistem zonasi dalam penerimaan peserta didik baru, melalui layanan google form. Hasil studi pendahuluan diperoleh informasi: (1). Responden penelitian sudah menerapkan sistem zonasi. (2). Terdapat ketidaksesuaian peraturan zonasi dengan kebutuhan masyarakat. (3). Siswa berprestasi tidak dapat ditampung secara menyeluruh karena ada pembatasan kuota. (4). Belum pernah dilakukan evaluasi PPDB Sistem Zonasi. (5). Penting menyusun instrumen evaluasi. (6). Dampak sitem zonasi salahsatunya menurunkan prestasi di beberapa sekolah responden penelitian.Berdasarkan hasil studi pendahuluan, pentingnya dikembangkan instrumen evaluasi menggunakan model CIPP untuk mengevaluasi pelaksanaan PPDB. Stufflebeam (1972) bahwa Evaluasi model Stufflebeam terdiri dari empat dimensi, yaitu: context,input, process, dan product, sehingga model evaluasinya diberi nama CIPP. Evaluasi model ini bermaksud membandingkan kinerja dari berbagai dimensi program dengan sejumlah kriteria tertentu. Menurut model ini keempat dimensi program tersebut perlu dievaluasi sebelum, selama dan sesudah program diklat dikembangkan Mahmudi (2011) bahwa Model CIPP berpijak pada pandangan bahwa tujuan terpenting dari evaluasi program bukanlah membuktikan (to prove), melainkan meningkatkan (to improve). Model CIPP merupakan salah satu model yang banyak digunakan untuk mengevaluasi program pendidikan. Penelitian Musyaroh dan Sutrisno (2014) mengembangkan instrumen evaluasi program Tahfiz Alqur'an di Pondok Pondok Pesantren ditemukan kesenjangan sarana belajar, kinerja guru, dan motivasi belajar santri. Kurnia, Rosana, Supahar (2017) instrumen evaluasi model CIPP yang digunakan untuk mengevaluasi pelaksanaan penilaian portofolio dan hasilnya menunjukkan bahwa pelaksanaan penilaian portofolio di Sekolah Menengah Pertama di Yogyakarta berada dalam kategori baik. Asfaroh, Rosana, Supahar (2017) instrumen evaluasi model CIPP yang digunakan untuk mengevaluasi pelaksanaan penilaian proyek dan hasilnya menunjukkan bahwa pelaksanaan penilaian proyek di Sekolah Menengah Pertama di Yogyakarta berada dalam kategori baik.

\section{Tahap Design (merancang)}

Berdasarkan hasil studi pendahuluan, tahap berikutnya yaitu merancang instrumen evaluasi PPDB berbasis model CIPP. Merancang produk diawali dengan menyusun kisi-kisi dan menerjemahkan menjadi instrumen penelitian Hasil tahap merancangan sebagai berikut. a. Menyusun Kisi-Kisi

Kisi-kisi instrumen disusun berdasarkan kerangka teori model evluasi CIPP dan konteks peruturan penerimaan peserta didik baru sistem zonasi. Kisi-kisi instrumen sebagai berikut. 
Yusufi, Khoirurrohman, dan Kristyaningrum, Pengembangan Instrumen Evaluasi...171

Tabel 2. Kisi-Kisi Evaluasi Sistem Zonasi Model CIPP

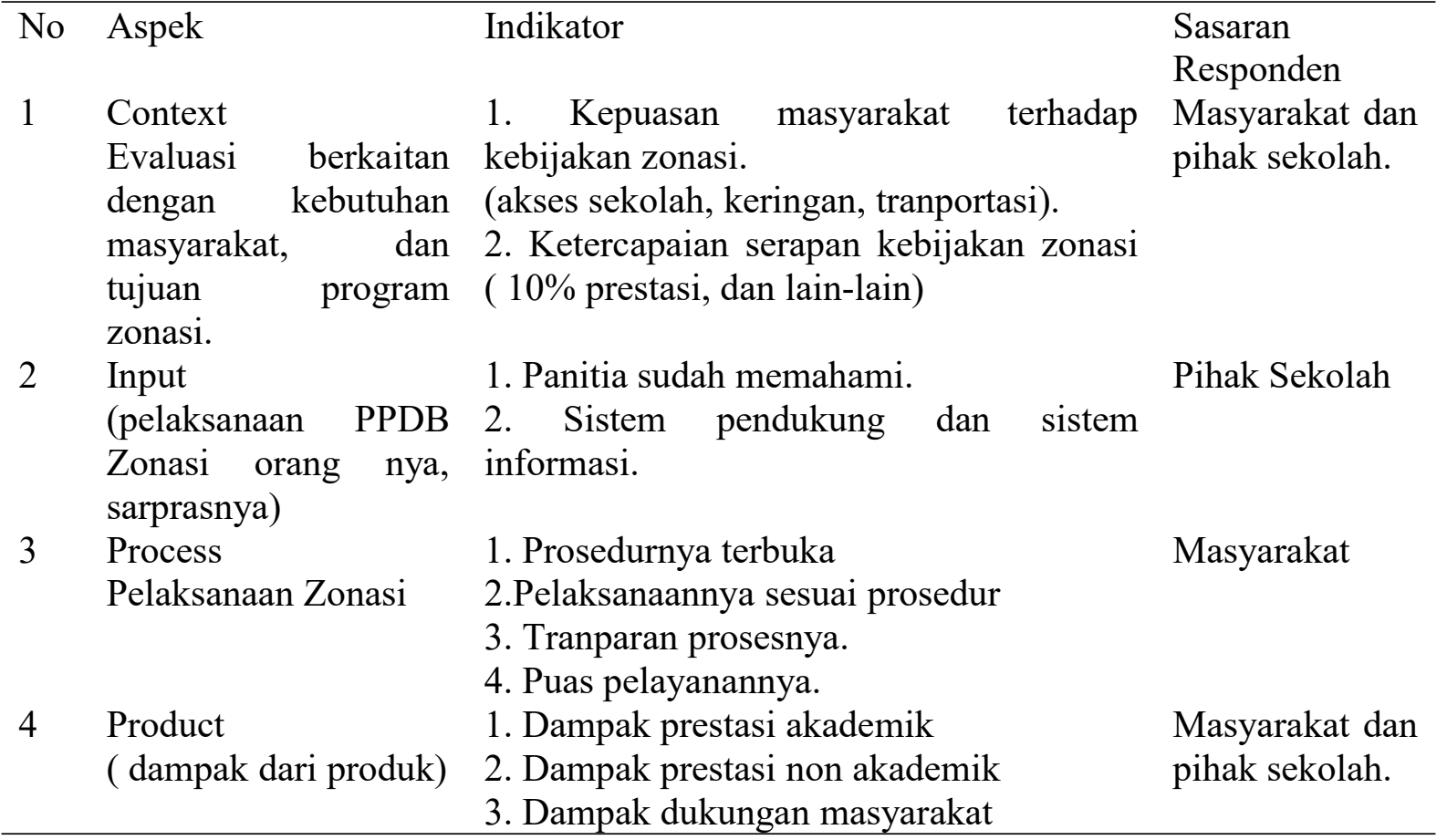

b. Mengembangkan Instrumen Evaluasi PPDB Sistem Zonasi Model CIPP

Item instrumen evaluasi PPDB sistem zonasi model CIPPP disusun berdasarkan kisi-kisi yang sudah disusun. Item instrumen evaluasi PPDB sebagai berikut.

1. Instrumen Evaluasi Aspek Konteks

\begin{tabular}{|c|c|c|}
\hline No & Aspek & Respon \\
\hline 1 & $\begin{array}{l}\text { Apakah peraturan sistem zonasi PPDB tingkat SMA membantu anda } \\
\text { memberikan keadilan bagi anda? }\end{array}$ & \\
\hline 2 & $\begin{array}{l}\text { Apakah Sistem zonasi memudahkan saya untuk mendapatkan pendidikan } \\
\text { yang berkualitas? }\end{array}$ & \\
\hline 3 & $\begin{array}{l}\text { Apakah Sistem zonasi mengurangi biaya transportasi karena lokasinya dekat } \\
\text { dengan rumah? }\end{array}$ & \\
\hline 4 & $\begin{array}{l}\text { Apakah Sistem zonasi mengurangi energi dan waktu karena lokasinya dekat } \\
\text { dengan rumah? }\end{array}$ & \\
\hline 5 & $\begin{array}{l}\text { Apakah sistem zonasi membantu keluarga yang kurang mampu untuk } \\
\text { mendapatkan pendidikan terjangkau? }\end{array}$ & \\
\hline 6 & $\begin{array}{l}\text { Apakah sistem zonasi meningkatkan angka partisipasi pendidikan di wilayah } \\
\text { bapak? }\end{array}$ & \\
\hline 7 & $\begin{array}{l}\text { Apakah kuota } 90 \% \text { untuk siswa yang masuk dalam zonasi dan siswa kurang } \\
\text { mampu? }\end{array}$ & \\
\hline 8 & Apakah kuota $5 \%$ untuk siswa jalur prestasi terpenuhi? & \\
\hline 9 & Apakah kuota $5 \%$ untuk siswa dari pindah domisili orang tua? & \\
\hline 19 & Apasaja kendala penerapan sistem zonasi ? & \\
\hline
\end{tabular}


2. Instrumen Evaluasi Aspek Input

\begin{tabular}{lll}
\hline No & Aspek & Respon \\
1 & Bagaimanakah pemahaman petugas PPDB Sistem Zonasi? & \\
2 & Bagaimana prosuder yang disusun panitia PPDB sistem zonasi ? & \\
3 & $\begin{array}{l}\text { Bagaimana penempatan petugas panitia PPDB sistem zonasi sesuai dengan } \\
\text { kemampuan? }\end{array}$ & \\
4 & $\begin{array}{l}\text { Bagaimana kesiapan sistem online PPDB sistem zonasi agar mudah diakses } \\
\text { dan dipahami oleh masyarakat? }\end{array}$ & \\
5 & $\begin{array}{l}\text { Bagaimana kesiapan infrastruktur (komputer, teknisi, dan perangkat lain) } \\
\text { dalam keadaan baik pada pelaksanaan PPDB? }\end{array}$ \\
\hline
\end{tabular}

3. Instrumen Evaluasi Aspek Proses
No Aspek
Respon

1 Bagaimana pelayanan panitia PPDB sistem zonasi untuk melaksanakan PPDB sesuai petunjuk teknis?

2 Bagaimana kejelasan prosuder yang disusun panitia PPDB sistem zonasi?

3 Bagaimana kecakapan (terampil) petugas panitia PPDB sistem zonasi sesuai dengan kemampuan?

$4 \quad$ Bagaimana kemudahan sistem online PPDB sistem zonasi ketika diakses dan dipahami oleh masyarakat?

$5 \quad$ Bagaimanah keadaan infrastruktur (komputer, teknisi, dan perangkat lain) dalam keadaan baik pada pelaksanaan PPDB?

$6 \quad$ Bagaimakah transparasi PPDB sistem zonasi?

7 Bagaimanakah kekurangan pelaksanaan PPDB sistem zonasi?

8 Bagaimanakah kelebihan pelaksanaan PPDB sistem zonasi?

9 Apakah sistem zonasi meningkatkan partisipasi masyarakat untuk bersekolah?

$10 \quad$ Apakah sistem zonasi menerapkan azaz keadilan dan pemerataan?

\section{Instrumen Evaluasi Aspek Produk}

\begin{tabular}{lll} 
No & Aspek & Respon \\
1 & $\begin{array}{l}\text { Bagaimana dampak prestasi akademik setelah kebijakan PPDB sistem zonasi? } \\
2\end{array}$ & $\begin{array}{l}\text { Bagaimana dampak prestasi non akademik setelah kebijakan PPDB sistem } \\
\text { zonasi? }\end{array}$ \\
3 & $\begin{array}{l}\text { Apakah ada perbedaan prestasi akademik dan non akademik sebelum dan } \\
\text { setelah kebijakan PPDB sistem zonasi? }\end{array}$ \\
4 & $\begin{array}{l}\text { Bagaimanakah peningkatan partisipasi masyarakat sekitar untuk bersekolah } \\
\text { setelah kebijakan PPDB sistem zonasi? }\end{array}$ \\
5 & $\begin{array}{l}\text { Bagaimanakah dukungan masyarakat sekitar terhadap pngeloaan sekolah } \\
\text { setelah kebijakan PPDB sistem zonasi? }\end{array}$ \\
\hline
\end{tabular}

\section{c. Validasi Produk}

Hasil validasi yang diberikan oleh validator diperoleh informasi bahwa instrumen evaluasi layak digunakan. Penilian validator terhadap produk yang dikembangkan rata-rata "A" dengan predikat sangat baik. Penilaian validator disajikan dalam Tabel 3. 
Yusufi, Khoirurrohman, dan Kristyaningrum, Pengembangan Instrumen Evaluasi ...173

Tabel 3. Konversi Penilaian Validator

\begin{tabular}{|c|c|c|c|c|}
\hline No & Validator & $\begin{array}{l}\text { Rerata } \\
\text { Penilaian } \\
\text { Produk }\end{array}$ & Interval Skor & Nilai \\
\hline 1. & $\begin{array}{l}\text { Dosen Metode } \\
\text { Penelitian }\end{array}$ & 4,0 & $\mathrm{X}>\mathrm{Xi}+1,5 \mathrm{Sbi}$ & A \\
\hline 2. & Dosen Evaluasi & 4,0 & $\mathrm{Xi}+\mathrm{Sbi}<\mathrm{X}<\mathrm{Xi}+1,5 \mathrm{Sbi}$ & A \\
\hline 3. & Kepala Sekolah & 4,0 & $\mathrm{Xi}-0,5 \mathrm{Sbi}<\mathrm{X}<\mathrm{Xi}+1,5 \mathrm{Sbi}$ & A \\
\hline 4. & Panitia PPDB & 4,2 & $\mathrm{Xi}-1,5 \mathrm{Sbi}<\mathrm{X}<\mathrm{Xi}-0,5 \mathrm{Sbi}$ & A \\
\hline 5. & Teman Sejawat & 4,4 & $\mathrm{X}<\mathrm{Xi}-1,5 \mathrm{Sbi}$ & A \\
\hline
\end{tabular}

Selain penilaian oleh validator berupa angka, validator memberikan penilaian berupa saran perbaikan terhadap produk. Saran yang diberikan oleh validator sebagai berikut: (1). Kalimat yang digunakan perlu memperhatikan EYD. (2). Jumlah item pertanyaan harus mencakup indikator yang diteliti. (3). Karena pandemi, disediakan akses soft file dari produk ini.

\section{Uji Implementasi Produk}

Pelaksanaan uji produk instrumen evaluasi PPBD sistem zonasi berdasarkan model CIPP tingkat Sekolah Menengah Atas (SMA) mengalami kendala. Adanya pandemi Covid 19 dari bulan Maret 2020 kegiatan penelitian yang mengharuskan bertemu siswa, orang tua, dan pihak sekolah mengalami kesulitan pemberian izin mengambil data. Oleh karena itu, uji implementasi produk tidak dapat dilakukan.

\section{Pembahasan}

Dalam praktiknya, sistem zonasi PPDB menuai pro kontra di sejumlah daerah, termasuk di Kabupaten Brebes. Data studi pendahuluan tahun 2019 tentang permasalahan di Brebes yaitu sejumlah tujuh belas SMA Negeri hanya satu sekolah yang daya tampungnya terpenuhi sebanyak 408 siswa. Permasalahan tentang PPDB yaitu kesalahan sistem ini membuat puluhan calon siswa yang akan mendaftar, berkaitan dengan perpindahan tempat tinggal tiba-tiba, kewajiban menerima 90 persen calon siswa yang tinggal di lokasi dekat sekolah. Di lapangan, hal ini membuat sekolah yang jauh dari konsentrasi pemukiman warga biasanya ada di pusat kota sepi peminat sehingga menimbulkan ketimpangan karena ada sekolah yang pendaftarnya melebihi kuota dan ada sekolah yang sepi pendaftar. Oleh karena itu, peneletian pengembangan instrumen evaluasi model CIPP, perlu dilakukan.

Data yang diperoleh berdasarkan kegiatan penelitian langkah satu sampai empat. Studi pendahuluan diperoleh informasi bahwa penting dikembangkan instrumen evaluasi model CIPP. Alasannya, pelaksanaan PPDB belum dilakukan oleh tingkat sekolah. Aplikasi PPDB yang diluncurkan dinas pendidikan tingkat Provinsi langsung digunakan di sekolah. Namun, pada pelaksanaannya memunculkan permasalahan. Selain itu, PPDB menjadi hal yang penting dalam institusi sekolah, karena melalui PPDB diperoleh input siswa yang dapat meningkatkan kualitas lulusan sekolah. Topik evaluasi sistem zonasi lebih banyak menyoroti implementasi PPBD dan belum membahas instrumen penelitian. Penelitian tentang evaluasi penerimaan sistem zonasi di luarnegeri Poder, Lauri, Veski (2016) kebijakan sistem zonasi tidak mempengaruhi orang tua siswa memilih sekolah 
negeri akan tetapi persepsi kualitas sekolah yang menjadi faktor pemilihan sekolah bagi anaknya. PPTA (2004) Analisis data tentang zona pendaftaran sekolah di Auckland menunjukkan bahwa sekolah yang lebih makmur sering menggunakan batas zona untuk mengecualikan siswa yang paling tidak beruntung dan mengadopsi praktik pendaftaran untuk menambah pendanaan dari orang tua yang memiliki ekomomi tinggi sehingga membatasi kesempatan untuk kurang beruntung.Irawati, Purwanti, dan Adiwisasatra,dkk (2019) disimpulkan kebijakan sistem zonasi terbukti dapat meningkatkan angka partisipasi kasar dari siswa RMP,karena faktanya tidak semua anak RMP berdomisili di dekat sekolah. Marini (2019) hambatan yang ditemukan PPDB sistem zonasi yakni aplikasi yang disediakan mengalami gangguan, jaringan kurang memadai, kuota diluar sistem zonasi mempengaruhi tidak terpenuhinya daya tampung. Perdana (2019) pelaksanaan PPDB Zonasi di Provinsi Sulawesi Tengah telah berhasil dalam upaya memeratakan akses dan mutu pendidikan. Sebaran siswa dari sisi jarak sudah mendekat ke rumah siswa dan dari sisi mutu input juga telah menyebar di berbagai sekolah sehingga sudah tidak ada lagi dikotomi sekolah unggulan dan non unggulan. Ardhi (2015) Implementasi PPDB dengan mekanisme zonasi menimbulkan masalah yaitu masih belum disosialisasikan, terkendala oleh faktor teknis, kuota penerimaan siswa baru yang kurang, dan persaingan yang tinggi antar sekolah. Jatiprasetyo (2018) rekomendasi berdasarkan hasil penelitian kepada pemerintah untuk melanjutkan kebijakan ini, mempromosikan moda transportasi umum serta moda transportasi sehat bagi pelajar, penambahan kapasitas daya tampung sekolah negeri, serta evaluasi lebih lanjut secara komprehensif terhadap kebijakan sistem zonasi ini. Widayanti dan Rosdiana (2018) hasil evaluasi berhasil dilaksanakan sesuai dengan pedoman petunjuk teknis PPDB, meskipun terdapat masalah jalur mitra warga memiliki peminat yang rendah.

Karakteristik penelitian ini yaitu menggunakan teori evaluasi model CIPP. Evaluasi pendidikan adalah proses membuat penilaian tentang prestasi, nilai, atau nilai program pendidikan (Gall, Gall and Borg, 2007:559). Peneriamaan Peserta Didik Baru (PPBD) sistem zonasi merupakan sebuah program yang diselnggarakan sekolah. Sanders (1979) yang dikutip (Murzyanah, 2011) mengatakan evaluasi program merupakan proses deskripsi, pengumpulan data dan penyampaian informasi kepada pengambil keputusan yang akan dipakai untuk pertimbangan apakah program perlu diperbaiki, dihentikan atau diteruskan. Tujuan evaluasi program seperti yang duraikan oleh Roswati (2008) adalah sebagai berikut: 1) menjawab pertanyaan-pertanyaan tentang tindak lanjut suatu program di masa depan, 2) penundaan pengambilan keputusan, 3) penggeseran tanggung jawab, 4) pembenaran/justifikasi program, 5) memenuhi kebutuhan akreditasi, 6) laporan akutansi untuk pendanaan, 7) menjawab atas permintaan pemberi tugas, informasi yang diperlukan, 8) membantu staf mengembangkan program, 9) mempelajari dampak/akibat yang tidak sesuai dengan rencana, 10) mengadakan usaha perbaikan bagi program yang sedang berjalan, 11) menilai manfaat dari program yang sedang berjalan, 12) memberikan masukan bagi program baru. Penelitian tentang evaluasi program pada PPDB sistem zonasi belum banyak mengungkap instrumen evaluasi PPDB sistem zonasi.

Instrumen penelitian yang dihasilkan mencakup model CIPP dari pelaksanaan evaluasi. Item Context Evaluasi berkaitan dengan kebutuhan masyarakat, dan tujuan program zonasi apakah sudah sesuai dengan tujuan atau belum. Aspek input berkaitan dengan pelaksanaan PPDB Zonasi dengan komponen pelaku (panitia PPDB), sarprasnya (infrastruktur) jarigan komputer, internet, dan media komunikasi. Aspek, process berkaitan dengan pelaksanaan PPDB zonasi yang diawali proses sosialisasi, pendaftaran, seleksi, 
pengumuman, proses pembelajaran. Aspek product berkaitan dengan hasil PPDB yaitu pencapaian prestasi siswa, prestasi sekolah setelah diterapkannya sistem zonasi PPDB. Data penilaian validator terhadap instrumen evaluasi PPDB model CIPP disimpulkan sangat baik digunakan untk melakukan evaluasi PPDB tingkat SMA di Brebes. Menurutnya, instrumen yang dikembangkan memenuhi aspek model CIPP dan kepraktisan digunakan di sekolah. Hasil penilaian validator disajikan pada Gambar 1.

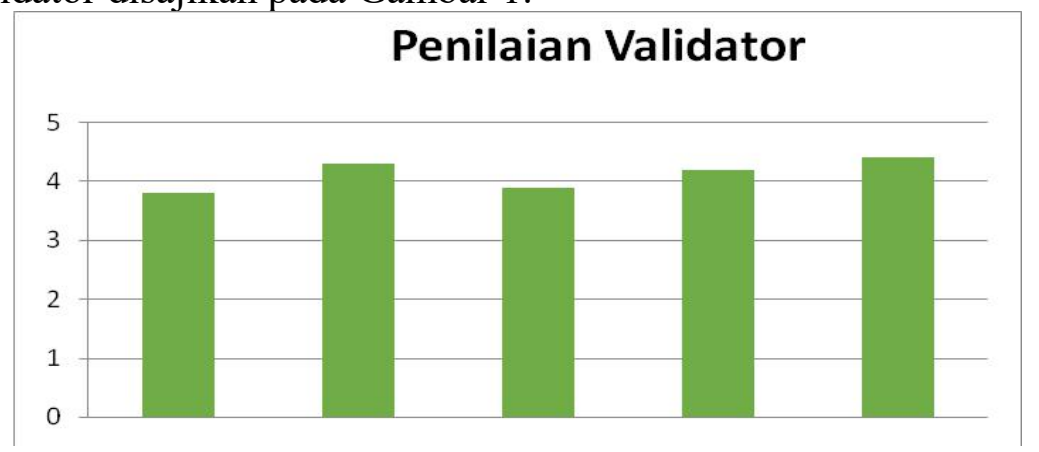

Gambar 1. Penilaian Validator

Simpulan dan Saran

Berdasarkan hasil penelitian dan pembahasan dapat disimpulkan instrument evaluasi PPDB sistem zonasi berdasarkan model CIPP dikembangkan melalui tahap 4D yang terdiri dari define, design, develop dan dissemination layak dan valid digunakan di lapangan. Saran kepada penelitian lain yaitu mengembangkan instrument evaluasi PPDB sistem zonasi terintegrasi sistem informasi secara secara online sehingga mudah diakses oleh pihak yang terlibat.

\section{Daftar Rujukan}

Adiwisastra, J. Irawati, I. and Purwanti, D. (2018). Efektivitas Kebijakan Penerimaan Peserta Didik Baru Sistem Zonasi Bagi Siswa Rawan Melanjutkan Pendidikan, Jurnal Dinamika, 5(4):1-7.

Borg, W.R. \& Gall, M.D. (1983). Educational Research. New York London: Longman.

Kaire Põder, Triin Lauri \& Andre Veski. 2016. Does School Admission by Zoning Affect Educational Inequality? A Study of Family Background Effect in Estonia, Finland, and Sweden, Scandinavian Journal Of Educational Research, http://dx.doi.org/10.1080/00313831.2016.1173094

Mahmudi, I. (2011). CIPP: Suatu Model Evaluasi Program Pendidikan. Jurnal At-Ta'dib, 6 (1):1-15.

Mardapi, D. (2008). Teknik Mardapi, D. (2008). Teknik Penyusunan Instrumen Tes dan Nontes. Yogyakarta: MITRA CENDIKIA Press.

Marini, K. (2019). Implementasi Kebijakan Sistem Zonasi Dalam Penerimaan Peserta Didik Baru (Ppdb) Pada Sma Negeri Di Kota Bandar Lampung, Skripsi: UNILA Lampung. $\quad$ Diakes dari: http://digilib.unila.ac.id/56650/4/SKRIPSI\%20TANPA\%20BAB\%20PEMBAHASA N.p df

Muyararoh \& Sutrisno. (2014). Pengembangan Instrumen Evaluasi Cipp Pada Program 
Pembelajaran Tahfiz Al-Qur'an Di Pondok Pesantren, Jurnal Penelitian dan Evaluasi, 18 (2): 213-235.

Muzayanah. (2011). Evaluasi Program Pendidikan. Jakarta: Prodi Teknologi Pendidikan UNJ

Perdana, N.S. (2019). Implementasi PPDB Zonasi Dalam Upaya Pemerataan Akses Dan Mutu Pendidikan.Jurnal Pendidikan Glasser: 3 (1): 78-92

Permendiknas. (2018). No. 14 Tahun 2018 tentang Penerimaan Peserta Didik Baru pada Taman Kanak-Kanak, Sekolah Dasar, Sekolah Menengah Pertama, Sekolah Menengah Atas, Sekolah Menengah Kejuruan, atau Bentuk Lain yang Sederajat. Diambil https://jdih.kemdikbud.go.id/arsip/PERMENDIKBUD\%20NOMOR\%2051\%20TAH UN\%202018.pdf pukul 18.00

Prasetyo, J. (2018). Evaluasi Dampak Kebijakan Sistem Zonasi PPDB Terhadap Jarak Tempat Tinggal Dan Biaya Transportasi Pelajar SMA Di DIY. Tesis. Diunduh dari http://etd.repository.ugm.ac.id/

Roswati. (2008). Evaluasi Program/Proyek (Pengertian, Fungsi, Jenis, dan Format Usulan), Jurnal Pendidikan Penabur, http://www.bpkpenabur.or.id/files/Hal.\%206471\%20Evaluasi\%20Progra m.pdf. Diambil 12 Juni 201916.

Stufflebeam, D. L. 2003. The CIPP Model for Evaluation: the Article Presented at the 2003 Annual Conference of the Oregon Program Evaluators Network (OPEN) 3 October 2003 (online). (http://www.wmich.edu, diakses 18 Juli 219). 17.

Supahar., Asfaroh, J.A., Rosana, D. 2017. Development of CIPP Model of Evaluation Instrument on the Implementation of Project Assessment in Science Learning, International Journal of Environmental and Science Education (IJESE), 12 (1): 78-92

Supahar., Kurnia,F., Rosana, D. 2018. Developing evaluation instrument based on CIPP models on the implementation of portfolio assessment, AIP Conference Proceedings

Suparyono, Ipar. 2011. Analisis Sistem Administrasi Penerimaan Peserta Didik Baru Oonline SMA Negeri Provinsi DKI Jakarta. Jakarta: Tesis Universitas Gunadarma, http://library.gunadarma.ac.id//repository/view/3752285/ analisis-sistemadministrasipenerimaan-peserta-didik-baru-online-smanegeri-provinsi-dkijakarta.html.diunduh pada 2 Juni 2019.

Suwarto, S. (2009). Pengembangan tes dan analisis hasil tes yang terintegrasi dalam program komputer. Jurnal Penelitian dan Evaluasi Pendidikan, 13(1), 40-56.

Suwarto, S. (2017). Pengembangan tes ilmu pengetahuan alam terkomputerisasi. Jurnal Penelitian dan Evaluasi Pendidikan, 21(2), 153-161.

Stufflebeam, D. (1972). Educational Evaluation and Decising Making: Pecocok Publicers Inc.

Widyawati, D., Rosdiana, W. 2018. Evaluasi Kebijakan Penerimaan Peserta Didik Baru Di SMAN 22 Surabaya Tahun 2018, Jurnal Mahasiswa Unesa Diakses dari :https://jurnalmahasiswa.unesa.ac.id/index.php/publika/article/view/27380 